慶應義塾大学学術情報リポジトリ

Keio Associated Repository of Academic resouces

\begin{tabular}{|c|l|}
\hline Title & $\begin{array}{l}\text { CLASS DIFFERENCES IN MARRIAGE AND FERTILITY AMONG TOKUGAWA VILLAGERS IN MINO } \\
\text { PROVINCE }\end{array}$ \\
\hline Sub Title & \\
\hline Author & 速水, 融(HAYAMI, Akira) \\
\hline Publisher & Keio Economic Society, Keio University \\
\hline Publication year & 1980 \\
\hline Jtitle & Keio economic studies Vol.17, No.1 (1980.) ,p.1-16 \\
\hline JaLC DOI & \\
\hline Abstract & \\
\hline Notes & \\
\hline Genre & Journal Article \\
\hline URL & $\begin{array}{l}\text { https://koara.lib.keio.ac.jp/xoonips/modules/xoonips/detail.php?koara_id=AA00260492-1980000 } \\
1-0001\end{array}$ \\
\hline
\end{tabular}

慶應義塾大学学術情報リポジトリ(KOARA)に掲載されているコンテンツの著作権は、それぞれの著作者、学会または出版社/発行者に帰属し、その権利は著作権法によって 保護されています。引用にあたっては、著作権法を遵守してご利用ください。

The copyrights of content available on the KeiO Associated Repository of Academic resources (KOARA) belong to the respective authors, academic societies, or publishers/issuers, and these rights are protected by the Japanese Copyright Act. When quoting the content, please follow the Japanese copyright act. 


\title{
CLASS DIFFERENCES IN MARRIAGE AND FERTILITY AMONG TOKUGAWA VILLAGERS IN MINO PROVINCE*
}

\author{
Akira Hayami
}

\section{INTRODUCTION}

Progress in historical demographic analysis of the lives of Japanese villagers in the Tokugawa period (1603-1868) has shown that there are clear differences in their demographic behavior and indices by economic class. ${ }^{1}$ Professor Thomas $\mathrm{C}$. Smith, for example, shows in his research on the village of "Nakahara," that there are distinct class differences in age at marriage, life expectancy, family size, and so on (Smith, 1977). According to Susan B. Hanley and Kozo Yamamura's research on villages in Okayama, there are definite differences in, for example, average age at first and last birth by class. ${ }^{2}$ The author has demonstrated, in his research on the village of Nishijo in the province of Mino that there is a clear differential by class in migration. $^{3}$

Villagers by no means acted homogenously in demographic matters. Given this, it is necessary, if at all possible, to investigate the demographic behavior of the villagers by class. We must investigate the extent of this discrepancy-whether it is minimal or whether it is so large as to affect the reproductive rate-quantitatively, through statistical analysis.

This paper uses family reconstitution to derive indices of marriage and birth rates from observation of class differences in six villages on the Nobi plain (near Nagoya), site of the author's present research. Its object is fact-finding rather than analysis, so it explains the amount of differential through various charts and graphs. A more complete analysis, and comparison with previous results, particularly those of life expectancy, must be left until later.

\section{PREPARATION OF DOCUMENTS AND STATISTICS}

The six villages which form the basis for this study, all in the province of Mino, are the villages of Inuma, Ena county; Higashikaiden, Katagata county; Kano, Ōno county; Nishijo, Anpachi county; and Arioshinden and Nekojishinden, both

* Translated by Laurel L. Cornell, Department of Social Relations, Johns Hopkins University.

1 Records of kokudaka, listings of the value of housing and arable land owned by households within a village, and expressed in terms of measures of rice, are generally used as indicators of the economic status of Tokugawa-era villagers. In most cases these values reflect land surveys carried out in the last decade of the sixteenth or the earlier part of the seventeenth century.

2 Hanley and Yamamura (1977), Table 9.5, page 236.

${ }^{3}$ Hayami (1973a), Tables I and II, page 8. 
in Tagi county. Aside from Inuma, which is located to the east, in a hilly area, the villages are situated on a plain. The last three villages are wajū villages, built on land reclaimed from the surrounding fens and protected by dikes. Table 2.1 shows the period covered by the documents, the number of usable years of data, and the beginning and final year populations for each of the six villages. The earliest usable

TABLE 2.1. Coverage OF THE Shümon aratame chō

\begin{tabular}{lccc}
\hline \multirow{2}{*}{ Village } & \multicolumn{2}{c}{ Years } & \multirow{2}{*}{$\begin{array}{c}\text { Population } \\
\text { (beginning-end) }\end{array}$} \\
\cline { 2 - 3 } & Covered & Usable & \\
\hline Inuma & $1713-1868$ & $(111)^{*}$ & $331-369$ \\
Higashikaiden & $1665-1869$ & $(71)$ & $233-311$ \\
Kano & $1753-1868$ & $(65)$ & $134-168$ \\
Nishijo & $1773-1869$ & $(97)$ & $366-381$ \\
Arioshinden & $1685-1800$ & $(80)$ & $76-227$ \\
Nekojishinden & $1709-1865$ & $(53)$ & $371-579$ \\
\hline
\end{tabular}

* Figures in parentheses are number of years the documents are usable.

TABLE 2.2. Number of Families Reconstituted, by Village, FOR COMPleted AND UNCOMPleted Families, CoHort of WifE, AND Marriage CoHort

\begin{tabular}{|c|c|c|c|c|c|c|c|c|}
\hline & & Inuma & $\begin{array}{l}\text { Higashi- } \\
\text { Kaiden }\end{array}$ & Kano & Nishijo & $\begin{array}{l}\text { Ario- } \\
\text { Shinden }\end{array}$ & $\begin{array}{l}\text { Nekoji- } \\
\text { Shinden }\end{array}$ & Total \\
\hline \multicolumn{2}{|l|}{ Total of FRF } & 588 & 269 & 62 & 322 & 214 & 348 & 1803 \\
\hline \multicolumn{2}{|c|}{ Completed family } & 170 & 73 & 8 & 63 & 57 & 67 & 438 \\
\hline \multicolumn{2}{|c|}{ Uncompleted family } & 418 & 196 & 54 & 259 & 157 & 281 & 1365 \\
\hline \multicolumn{2}{|c|}{ Cohort of $1626-1650$} & 2 & & & & 3 & & 5 \\
\hline \multirow[t]{10}{*}{ wife } & $1651-1675$ & 34 & & & & 24 & & 58 \\
\hline & $1676-1700$ & 74 & 3 & 3 & & 40 & & 120 \\
\hline & $1701-1725$ & 72 & 26 & 14 & 20 & 52 & & 184 \\
\hline & $1726-1750$ & 66 & 37 & 16 & 49 & 50 & 13 & 231 \\
\hline & $1751-1775$ & 84 & 55 & 20 & 70 & 37 & 55 & 321 \\
\hline & $1776-1800$ & 69 & 54 & 9 & 67 & 8 & 101 & 308 \\
\hline & $1801-1825$ & 95 & 54 & & 58 & & 111 & 318 \\
\hline & $1826-1850$ & 86 & 40 & & 56 & & 68 & 250 \\
\hline & $1851-1875$ & 3 & & & 2 & & & 5 \\
\hline & unknown & 3 & & & & & & 3 \\
\hline \multirow{8}{*}{$\begin{array}{r}\text { Marriage } \\
\text { cohort }\end{array}$} & $1701-1725$ & 47 & & & 1 & 38 & & 86 \\
\hline & $1726-1750$ & 72 & 29 & 11 & 21 & 45 & & 178 \\
\hline & $1751-1775$ & 54 & 37 & 17 & 52 & 50 & & 210 \\
\hline & $1776-1800$ & 83 & 53 & 22 & 70 & 41 & & 269 \\
\hline & $1801-1825$ & 75 & 42 & 3 & 61 & & 103 & 284 \\
\hline & $1826-1850$ & 95 & 51 & & 58 & & 79 & 283 \\
\hline & $1851-1875$ & 73 & & & 52 & & 66 & 235 \\
\hline & unknown & 89 & 13 & 9 & 7 & 40 & 100 & 258 \\
\hline
\end{tabular}


records are from the end of the seventeenth century and, with one exception, they continue up until about the time of the Meiji Restoration in 1868. For the purposes of family reconstitution, however, large gaps in a series of documents limits their usable span of time. Deficient recording and large numbers of mistakes also restrict their use. The earliest registers of Higashikaiden, Arioshinden, and Nekojishinden are unusable for family reconstitution due to such deficiencies. As one can see from the table of marriage cohorts, Table 2.2, the family reconstitution forms (FRFs) do not include material from the seventeenth century. When, as in Nishijo, the date of marriage is included in the documents, one can construct and classify FRFs for marriage cohorts considerably in advance of the time the records are actually available.

Table 2.2 shows numbers of completed and uncompleted families, and cohort of wife's birth and marriage for each of the six villages. The timespan of cohorts is twenty-five years, but this figure has no intrinsic significance. A total of 1803 FRFs are used in this paper, and of these the number of completed families is 438 , or 24 percent. From a demographic standpoint this number is inadequate. But this amount of material, all from a single area, and all providing information for observing class differences in demographic indices, is the largest we have ever had. One cannot do detailed examination of each period or each village, so this paper will examine the evidence by aggregating the FRFs which cover these six villages over a period of two centuries.

In a family reconstitution study, the term "completed family" means a marriage which continues unbroken to the end of the wife's childbearing period, here defined as $50 \mathrm{sai}^{4}{ }^{4}$ This gives us detailed information on the measurement of fertility and the number of children born during the period. However, since the length of time covered by the sources is limited, and, for various reasons, there is a large number of incomplete marriages, the number of completed families, as shown in Table 2.2 is small.

There is no need to describe in detail the procedure for compiling FRFs from shümon aratame chō here. I have described the method of assembling the shümon aratame chō before, elsewhere. Once the Basic Data Sheets have been made, creating FRFs is rather simple. The most usual form of household in the shumon aratame cho from these villages is a small family, so confirming who is the child of which couple presents no great problem. The FRFs naturally take married couples as their units of observation, so children of men and women who are not married do not fall into our sample. If their number were large, there would be serious errors in the measurement of fertility. But in Nishijo, one of the six villages, they make up only 69 of the total of 993 births over the entire period.

\footnotetext{
4 The author uses the Japanese method of calculating age, expressed as sai, throughout. A child is considered on year old at its birth; at its first New Year's Day, and at each subsequent New Year's, it gains one year in age. Hence there may be a discrepancy of up to twelve months between a person's age counted by the Japanese and by the Western method. Subtracting a year from the Japanese age will suffice for general purposes.
} 
Finally, in dividing the FRFs by class, we have used the class position of the family at the time of marriage. The classes are as follows, by kokudaka: Class I, 10 $k o k u$ and above; Class II, from 2 koku up to $10 \mathrm{koku}$; Class III, under two koku. Class I is a class of families which cannot cultivate their own land entirely by their own laborpower, but are dependent on hired labor or on leasing their land to tenants. The families in Class III have little or no land of their own, and support themselves by borrowing land from others or by working as hired laborers on others' land. Class II, the intermediate one, is composed of families which, by and large, cultivate land which they own themselves.

Of course this is a rather rough division, and because the range of actual cases is continuous, it is difficult to draw a clear line of demarcation between classes. Another problem is that there is movement between classes. If there were a great deal of this, basing our demographic statistics on the class level at the beginning of marriage as listed in the FRFs, would produce erroneous results belying the title of this paper. When we examine the degree of change in class level between the beginning and the endpoint of marriage for the 1389 couples recorded in the FRFs, we see that, as Table 2.3 shows, there was no change in 76 percent of the cases. Thus, using class of ownership at the beginning of marriage provides a firm foundation for our examine of class differences. The number of cases of movement to a higher class is greater than the reverse. This is because there are many cases in this area where households that were established as branches of others and, at their establishment, were mizunomi-that is, households whose own land was nil-later received a parcel of land (or just a house and garden) from their main households.

TABle 2.3. Change in Class Standing, BEgINNING AND END OF MARriage

\begin{tabular}{lcc}
\hline \multicolumn{1}{c}{ Class } & Number & Percentage \\
\hline I-I & 112 & $73.2 \%$ \\
I-II & 29 & 19.0 \\
I-III & 12 & 7.8 \\
II-I & 20 & 5.2 \\
II-II & 274 & 71.5 \\
II-III & 89 & 23.2 \\
III-I & 9 & 1.1 \\
III-II & 173 & 20.2 \\
III-III & 673 & 78.7 \\
Total & 1389 & \\
Upwards & 202 & 14.5 \\
Downwards & 130 & 9.3 \\
No change & 1059 & 76.1 \\
\hline
\end{tabular}

\section{AGE AT MARRIAGE}

One can readily imagine that there might be class differences in the age at which men and women marry. For example, more prosperous classes might have the 
opportunity to marry earlier, and lower classes be forced to marry later. The author has noticed significant difference in average age at marriage for women of different classes in his work on the village of Nishijo. Tables 3.1 and 3.2 show these differences for men and women in the six villages. The cases used in these figures are those where it is clear that the husband's marriage is his first. In most cases women come from other villages, so the number of samples where one is sure that it is the wife's first marriage is very small. Here we have used the larger number of cases available to us, and therefore, in order to determine whether there is a difference in quality by class, or how the age at marriage is distributed, our investigation of the wife's age is not limited to first marriages. (When we look at the relationship between age at marriage and number of births we will examine their class difference by wife's age at first marriage.)

TABLE 3.1. Age at Marriage (male)

\begin{tabular}{|c|c|c|c|c|}
\hline \multirow{2}{*}{ Age } & \multicolumn{3}{|c|}{ Number } & \multirow{2}{*}{ Total } \\
\hline & Class I & II & III & \\
\hline 14 & & 1 & 1 & 2 \\
\hline 15 & 1 & & & 1 \\
\hline 16 & & & 3 & 3 \\
\hline 17 & 1 & 4 & 4 & 9 \\
\hline 18 & 1 & 5 & 12 & 18 \\
\hline 19 & 3 & 7 & 13 & 23 \\
\hline 20 & 1 & 9 & 18 & 28 \\
\hline 21 & 4 & 11 & 24 & 39 \\
\hline 22 & 5 & 12 & 27 & 44 \\
\hline 23 & 7 & 12 & 23 & 42 \\
\hline 24 & 5 & 14 & 29 & 48 \\
\hline 25 & 8 & 12 & 30 & 50 \\
\hline 26 & 10 & 13 & 28 & 51 \\
\hline 27 & 9 & 24 & 38 & 71 \\
\hline 28 & 11 & 15 & 34 & 60 \\
\hline 29 & 9 & 18 & 21 & 48 \\
\hline 30 & 5 & 14 & 25 & 44 \\
\hline 31 & 8 & 13 & 24 & 45 \\
\hline 32 & 3 & 12 & 20 & 35 \\
\hline 33 & 3 & 11 & 17 & 31 \\
\hline 34 & 4 & 13 & 19 & 36 \\
\hline 35 & 2 & 8 & 12 & 22 \\
\hline 36 & 2 & 4 & 20 & 26 \\
\hline 37 & 4 & 2 & 12 & 18 \\
\hline 38 & 1 & 3 & 8 & 12 \\
\hline 39 & 1 & 4 & 2 & 7 \\
\hline 40 & 1 & 2 & 3 & 6 \\
\hline Over 40 & 2 & 8 & 22 & 32 \\
\hline Total & 111 & 251 & 489 & 851 \\
\hline Mean & 27.9 & 28.1 & 28.1 & 28.1 \\
\hline S.D. & 4.99 & 5.35 & 5.48 & \\
\hline
\end{tabular}


TABle 3.2. Age at Marriage (female)

\begin{tabular}{|c|c|c|c|c|}
\hline \multirow{2}{*}{ Age } & \multicolumn{3}{|c|}{ Number } & \multirow{2}{*}{ Total } \\
\hline & Class I & II & III & \\
\hline 11 & & & 1 & 1 \\
\hline 12 & & & 3 & 3 \\
\hline 13 & 2 & & 3 & 5 \\
\hline 14 & 4 & 7 & 9 & 20 \\
\hline 15 & 6 & 10 & 11 & 27 \\
\hline 16 & 8 & 14 & 13 & 35 \\
\hline 17 & 20 & 23 & 27 & 70 \\
\hline 18 & 14 & 33 & 36 & 83 \\
\hline 19 & 14 & 29 & 39 & 82 \\
\hline 20 & 6 & 28 & 50 & 84 \\
\hline 21 & 7 & 18 & 44 & 69 \\
\hline 22 & 9 & 22 & 47 & 78 \\
\hline 23 & 8 & 14 & 34 & 56 \\
\hline 24 & 6 & 7 & 36 & 49 \\
\hline 25 & 1 & 8 & 18 & 27 \\
\hline 26 & 3 & 4 & 23 & 30 \\
\hline 27 & 1 & 6 & 20 & 27 \\
\hline 28 & & 6 & 13 & 19 \\
\hline 29 & & 3 & 20 & 23 \\
\hline 30 & & 6 & 7 & 13 \\
\hline 31 & & 2 & 11 & 13 \\
\hline 32 & & 2 & 3 & 5 \\
\hline 33 & & 1 & 3 & 4 \\
\hline 34 & 1 & 3 & 4 & 8 \\
\hline 35 & & 3 & 4 & 7 \\
\hline 36 & & 1 & 3 & 4 \\
\hline 37 & & & 2 & 2 \\
\hline 39 & & & & 2 \\
\hline 40 & & & & 1 \\
\hline Over 40 & 1 & 1 & & 2 \\
\hline Total & 111 & 251 & 487 & 849 \\
\hline Mean & 19.4 & 21.0 & 22.4 & 21.6 \\
\hline S.D. & 3.99 & 4.78 & 5.06 & \\
\hline
\end{tabular}

Table 3.1 shows that there is no significant difference by class in age at marriage for men. The modal age is 28 sai for men in class I, 27 sai for Classes II and III. Men's behaviour is homogenous.

However, in Table 3.2, which shows age at marriage for women, differences by class are evident. There is a three-year difference in age between Class I and Class III, and the value for Class II is situated directly in between these. The mode, with Class I at 17 sai, Class II at 18 sai, and Class III at 20 sai, parallels the mean completely. There are significant differences in age at marriage for women by class, and it is clear that the higher class marries earlier and the lower class later.

Analysis of labor migration (dekasegi) in Nishijo explains this by showing that 
TABle 3.3 Age Difference of Husband and Wife, by Class

\begin{tabular}{|c|c|c|c|c|}
\hline $\begin{array}{c}\text { Difference } \\
\text { (years) }\end{array}$ & Class I & II & III & Total \\
\hline-12 & & & 1 & 1 \\
\hline-10 & & & 1 & 1 \\
\hline-9 & & & 3 & 3 \\
\hline-7 & & & 3 & 3 \\
\hline-6 & & & 1 & 1 \\
\hline-5 & & & 2 & 2 \\
\hline-4 & & 2 & 5 & 7 \\
\hline-3 & & 4 & 8 & 12 \\
\hline-2 & & 7 & 11 & 18 \\
\hline-1 & 2 & 5 & 14 & 21 \\
\hline 0 & 1 & 6 & 22 & 29 \\
\hline+1 & 2 & 8 & 29 & 39 \\
\hline+2 & 6 & 11 & 27 & 44 \\
\hline+3 & 4 & 9 & 29 & 42 \\
\hline+4 & 7 & 12 & 49 & 68 \\
\hline+5 & 7 & 19 & 32 & 58 \\
\hline+6 & 8 & 18 & 43 & 69 \\
\hline+7 & 9 & 21 & 29 & 59 \\
\hline+8 & 11 & 18 & 26 & 55 \\
\hline+9 & 8 & 22 & 28 & 58 \\
\hline+10 & 9 & 16 & 21 & 46 \\
\hline+11 & 7 & 14 & 12 & 33 \\
\hline+12 & 4 & 9 & 16 & 29 \\
\hline+13 & 4 & 4 & 17 & 25 \\
\hline+14 & 7 & 7 & 13 & 27 \\
\hline+15 & 4 & 4 & 6 & 14 \\
\hline+16 & 1 & 3 & 5 & 9 \\
\hline+17 & 1 & 1 & 3 & 5 \\
\hline+18 & 1 & 7 & 7 & 15 \\
\hline+19 & 1 & 2 & & 3 \\
\hline+20 & 4 & 1 & 2 & 7 \\
\hline Over +20 & 1 & 3 & 7 & 11 \\
\hline Total & 109 & 233 & 472 & 814 \\
\hline Mean & +8.8 & +7.3 & +5.9 & +6.7 \\
\hline S.D. & 4.79 & 5.03 & 5.30 & \\
\hline
\end{tabular}

migration to cities by women of the lower classes is prevalent, and the practice of marrying only after one returns to the village is more common than among women of higher classes. ${ }^{5}$ This serves as a kind of population limitation among lower-class families in the village.

Differences in the relative age of husband and wife arise from these class differences. Table 3.3 shows the difference, by class, between wife's and husband's age at his first marriage. As one can see, the mean disparity varies by class. The

5 Hayami (1973b), Table 1, page 180. 
husband is most often eight years older in Class I, nine years older in Class II, and four years older in Class III, so that the age difference between spouses is wider for the higher class and narrower for the lower classes. In Class I there are only two cases, 1.8 percent of the total, where the wife is older than her husband. In Class II there are 18, 7.7 percent, and in Class III, 49 examples, coming to 10.4 percent of the total number of cases. In the highest class, a wife being older than her husband is exceptional; in the lower class where more than a tenth of the women are older than their husbands, this nicety is unimportant.

\section{DURATION OF MARRIAGE}

Table 4.1 shows the distribution of the duration of marriage by class for the 609 couples whose beginning and ending dates of marriage can be ascertained. Since the records of the villages of Inuma and Kano include couples who have left the village permanently, these two villages are ignored and the results are based on data from the other four villages. ${ }^{6}$ There is a significant difference of about four years between Class II and Class III (but not significant between Class I and Class II). What can be termed the "curve of survival rate" for duration of marriage is shown in Figure 4.1. We can discover several important facts by inspecting this graph. First, Class II's "marriage survival rate" is generally greater than Class I's, but they change at about the same rate. In contrast to this, the level of Class III is rather low, and, particularly at a duration of twenty years, becomes 14 percent lower than Class I. About 60 percent of marriages in Class III end in less than twenty years, and the conditions of marriage are less stable than in the other classes.

Couples whose marriages endure for 25 years - that is, until their silver wedding anniversary-make up 40.2 percent of Class I, 42.7 percent of Class II, and 31.8 percent of Class III. Those who celebrate their golden wedding anniversary marking fifty years of marriage number only about 2 percent in each class.

One can explain part of this difference in duration of marriage by class by the clear differences in the wife's age at marriage. Wives of Class III marry, on the average, four years later than those of Class II. But the difference cannot be due solely to this. I think that the reason that most marriages in Class III end within twenty years is that poverty promotes their instability.

\footnotetext{
6 Two different methods were used in constructing the shümon aratame chō; the principle of permanent residence and the principle of actual residence. In the first method, persons born in a village continued to be registered in the shümon aratame chō there, even if they moved to another village. There were probably not very many cases where villagers in the Tokugawa period left their place of permanent residence, but in villages where the shümon aratame chō are constructed on the permanent residence principle, one sometimes finds listings of men and women, or couples who are extremely elderly and who are actually not living in the village, or even alive. Registers complied on the latter principle do not have this defect and show the population which actually lives in the village. The four villages used here are of this type. Since these documents are especially useful for the purpose of creating population statistics, in future I hope to search actively for them.
} 
TABLE 4.1. Duration of Marriage, By Class (number/cumulative total)

\begin{tabular}{|c|c|c|c|c|}
\hline Years & Class I & Class II & Class III & Total \\
\hline 1 & $5 / 97$ & $4 / 160$ & $29 / 314$ & $38 / 571$ \\
\hline 2 & $4 / 93$ & $5 / 155$ & $19 / 295$ & $28 / 543$ \\
\hline 3 & $5 / 88$ & $7 / 148$ & $6 / 289$ & $18 / 525$ \\
\hline 4 & $2 / 86$ & $6 / 142$ & $14 / 275$ & $22 / 503$ \\
\hline 5 & $2 / 84$ & $5 / 137$ & $14 / 261$ & $21 / 482$ \\
\hline 6 & $/ 84$ & $4 / 133$ & $7 / 254$ & $11 / 471$ \\
\hline 7 & $4 / 80$ & $2 / 131$ & $12 / 242$ & $18 / 453$ \\
\hline 8 & $4 / 76$ & $4 / 127$ & $8 / 234$ & $16 / 437$ \\
\hline 9 & $1 / 75$ & $4 / 123$ & $13 / 221$ & $18 / 419$ \\
\hline 10 & $3 / 72$ & $3 / 120$ & $9 / 212$ & $15 / 404$ \\
\hline 11 & $5 / 67$ & $3 / 117$ & $8 / 204$ & $16 / 388$ \\
\hline 12 & $2 / 65$ & $8 / 109$ & $10 / 194$ & $20 / 368$ \\
\hline 13 & $3 / 62$ & $2 / 107$ & $9 / 185$ & $14 / 354$ \\
\hline 14 & $3 / 59$ & $3 / 104$ & $10 / 175$ & $16 / 338$ \\
\hline 15 & 159 & $3 / 101$ & $5 / 170$ & $8 / 330$ \\
\hline 16 & $3 / 56$ & $5 / 96$ & $6 / 164$ & $14 / 316$ \\
\hline 17 & $1 / 55$ & $3 / 93$ & $5 / 159$ & $9 / 307$ \\
\hline 18 & $1 / 54$ & $3 / 90$ & $7 / 152$ & $11 / 296$ \\
\hline 19 & $1 / 53$ & $1 / 89$ & $9 / 143$ & $11 / 285$ \\
\hline 20 & $1 / 52$ & / 89 & $3 / 140$ & $4 / 281$ \\
\hline 21 & $/ 52$ & $4 / 85$ & $4 / 136$ & $8 / 273$ \\
\hline 22 & $2 / 50$ & $1 / 84$ & $4 / 132$ & $7 / 266$ \\
\hline 23 & $4 / 46$ & $8 / 76$ & $5 / 127$ & $17 / 249$ \\
\hline 24 & $3 / 43$ & $3 / 73$ & $12 / 115$ & $18 / 231$ \\
\hline 25 & $2 / 41$ & $3 / 70$ & $6 / 109$ & $11 / 220$ \\
\hline 26 & $2 / 39$ & $3 / 67$ & $9 / 100$ & $14 / 206$ \\
\hline 27 & $5 / 34$ & $3 / 64$ & $6 / 94$ & $14 / 192$ \\
\hline 28 & $1 / 33$ & $5 / 59$ & $6 / 88$ & $12 / 180$ \\
\hline 29 & $1 / 32$ & $3 / 56$ & $3 / 85$ & $7 / 173$ \\
\hline 30 & $3 / 29$ & $8 / 48$ & $4 / 81$ & $15 / 158$ \\
\hline 31 & $3 / 26$ & 4/ 44 & $2 / 79$ & $9 / 149$ \\
\hline 32 & $3 / 23$ & $4 / 40$ & $8 / 71$ & $15 / 134$ \\
\hline 33 & $3 / 20$ & $2 / 38$ & $7 / 64$ & $12 / 122$ \\
\hline 34 & $1 / 19$ & $2 / 36$ & $2 / 62$ & $5 / 117$ \\
\hline 35 & $/ 19$ & $1 / 35$ & $6 / 56$ & $7 / 110$ \\
\hline 36 & $3 / 16$ & / 35 & $6 / 50$ & $9 / 101$ \\
\hline 37 & $2 / 14$ & $2 / 33$ & $5 / 45$ & $9 / 92$ \\
\hline 38 & $2 / 12$ & $2 / 31$ & $5 / 40$ & $9 / 83$ \\
\hline 39 & $1 / 11$ & $8 / 23$ & $6 / 34$ & $15 / 68$ \\
\hline 40 & $1 / 10$ & $1 / 22$ & $6 / 28$ & $8 / 60$ \\
\hline 41 & $/ 10$ & $2 / 20$ & $3 / 25$ & $5 / 55$ \\
\hline 42 & $1 / 9$ & $3 / 17$ & $4 / 21$ & $8 / 47$ \\
\hline 43 & $1 / 8$ & $3 / 14$ & $3 / 18$ & $7 / 40$ \\
\hline 44 & $1 / 7$ & $2 / 12$ & $2 / 16$ & $5 / 35$ \\
\hline 45 & $1 / 6$ & $1 / 11$ & $2 / 14$ & $4 / 31$ \\
\hline 46 & $3 / 3$ & $2 / 9$ & $1 / 13$ & $6 / 25$ \\
\hline 47 & $/ 3$ & $3 / 6$ & $2 / 11$ & $5 / 20$ \\
\hline 48 & $/ 3$ & 1/ 5 & $5 / 6$ & $6 / 14$ \\
\hline 49 & $1 / 2$ & $1 / 4$ & $/ 6$ & $2 / 12$ \\
\hline 50 & 12 & $2 / 2$ & 16 & $2 / 10$ \\
\hline
\end{tabular}


TABLE 4.1. CONTINUED.

\begin{tabular}{|c|c|c|c|c|c|}
\hline Years & Class I & Class II & Class III & Total & \\
\hline 51 & 12 & 12 & $1 / 5$ & $3 /$ & 9 \\
\hline 52 & 12 & 1/ 1 & 15 & $3 /$ & 8 \\
\hline 54 & $1 / 1$ & 11 & $2 / 3$ & $2 /$ & 5 \\
\hline 55 & $/ 1$ & / 1 & 1/ 2 & $1 /$ & 4 \\
\hline 57 & $/ 1$ & $1 / 0$ & 12 & $2 /$ & 3 \\
\hline 58 & $/ 1$ & & $1 / 1$ & $1 /$ & 2 \\
\hline 65 & $/ 1$ & & $1 / 0$ & $1 /$ & 1 \\
\hline 68 & $1 / 0$ & & & $1 /$ & 0 \\
\hline Total & 102 & 164 & 343 & 609 & \\
\hline Mean & 21.2 & 22.3 & 18.6 & 20.1 & \\
\hline S.D. & 14.55 & 14.38 & 14.35 & & \\
\hline
\end{tabular}

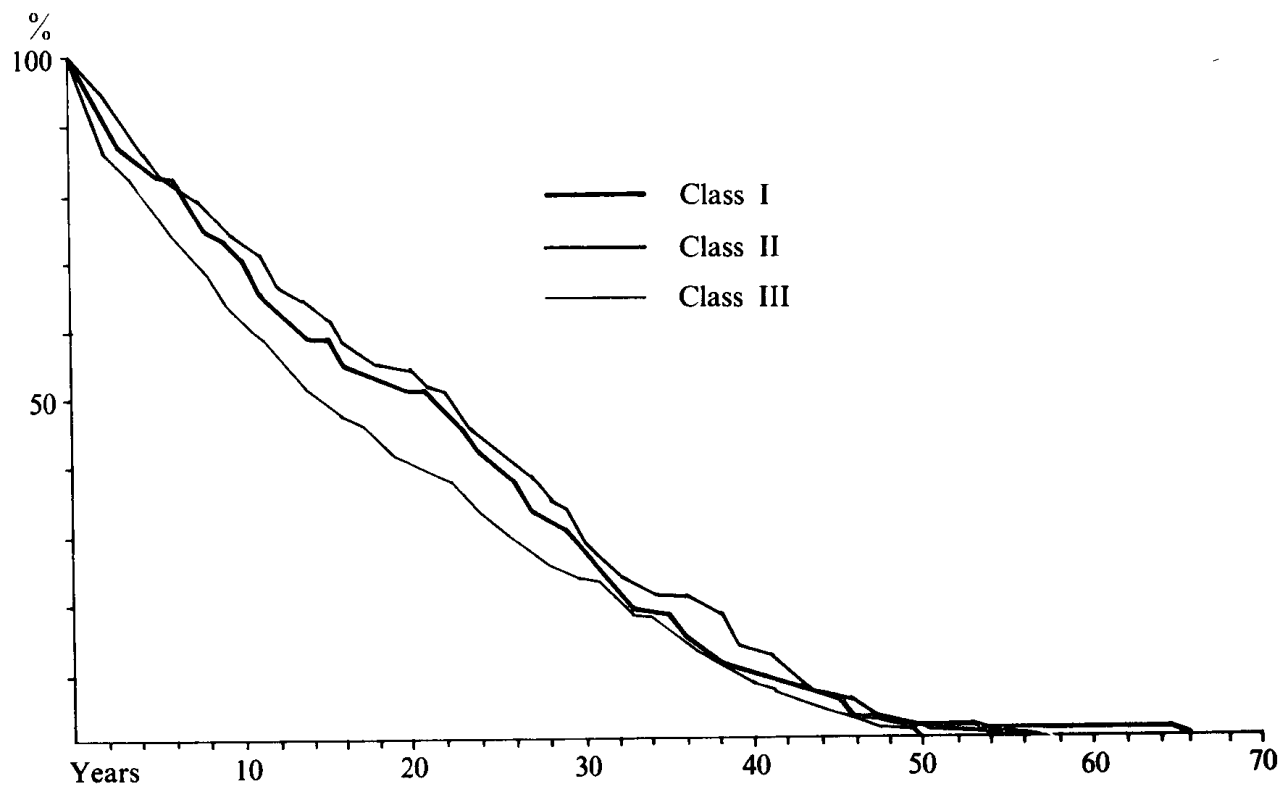

Fig. 4.1. Duration of marriage, by class.

Table 4.2 shows the class status of each of the partners in a marriage. In assigning men and women to classes it was possible to include only those examples where it was clear into which class each person was born - that is, only those where both spouses married within the same village. For both the men and women, cases where the spouse was originally from the same economic class are most common. The number of most divergent cases, where one of the spouses is from Class I and the other from Class III, is only a small part of the total. One can observe some marriages between the neighboring Classes I and II, but marriage within the same class accounts for about 80 percent of all marriages in Class III. One must say that 
TABle 4.2. Comparative Class Status of Husband and Wife

\begin{tabular}{llrrrr}
\hline \hline & & \multicolumn{3}{c}{ Class of Husband } & \multirow{2}{*}{ Total } \\
\cline { 3 - 5 } & & I & II & III & \\
\hline \multirow{2}{*}{ Class of wife } & I & 18 & 13 & 3 & 34 \\
& II & 17 & 31 & 33 & 81 \\
& III & 1 & 26 & 141 & 168 \\
& Total & 36 & 70 & 177 & 283 \\
\hline
\end{tabular}

the opportunity to rise out of Class III by marriage was very limited.

\section{BIRTHS AND FERTILITY}

Family reconstruction is, to begin with, a technique developed in order to measure fertility, and its greatest importance lies in the possibility of creating the crucial index measure of age-specific fertility. However, though it is usually so treated, fertility as reflected in the shümon aratame chō is in fact not actual fertility. Stillbirths are not recorded in the registers, of course. Also, since the documents were compiled only once a year, persons born after the date when registers were compiled in one year, and dying before the next year's registration date, are not counted either.

It is reasonable to assume that infant mortality was rather high, and consequently, the number of births that could have been counted in the registers is somewhat lower than the actual number of births. We do not have very much evidence about how great this underestimation was, but we can obtain an estimate of the number of concealed births and deaths based on Hiroshi Kito's research using a kainin kakiagecho-a document listing pregnant wives to whom a sort of subsidy should be given-from a village in northeastern Japan in the early nineteenth century (Kito, 1976). According to Kito, there were 271 births in this village from 1808 through 1826, of which 21 were stillbirths. Of the remaining 250 births, 241 were unquestionably live births, and of these 41 infants died within the first year of life. For the 32 of these whose month and day of death is known, 16 died within four weeks of birth, 9 died between four weeks and three months, 4 between three and six months, 2 between six and nine months, and one between nine months and a year of birth. The total calculation shows that 29 infants died within their first six months of birth, 12 percent of the total number of births. If we include those whose date of death is unknown, we can presume that about twenty percent of all live-born infants died within six months. If we use these figures, acknowledging that it requires a certain amount of boldness to vault over the spacial and temporal distance and apply these to a different location in Tokugawa Japan, and recognizing that, at this point, these are the only figures calculated directly from such sources that we have, the following inferences are possible. 
Suppose there are 1000 actual births. Of these, 200 die within the first six months of birth. Eight hundred persons remain. If we assume that there is no seasonal bias in births, these 800 persons will be the figures that we will capture as "births" in the shümon aratame cho from its compilation in one year to its compilation in the next. In comparison to the 800 "births" listed in the records, there are 200 , that is 25 percent, births and deaths which go unrecorded. For this reason it is necessary to adjust the number of births upwards by about 25 percent in calculating fertility. Needless to say, one must also make adjustments in the mortality figures. It is incumbent on a researcher to make such adjustments when comparing these figures with fertility figures from a modern census, but such an adjustment is not necessary when comparing the results with other calculations based on the shumon aratame $c h \bar{o}$. In this paper no adjustment has been made in either numerical values or fertility.

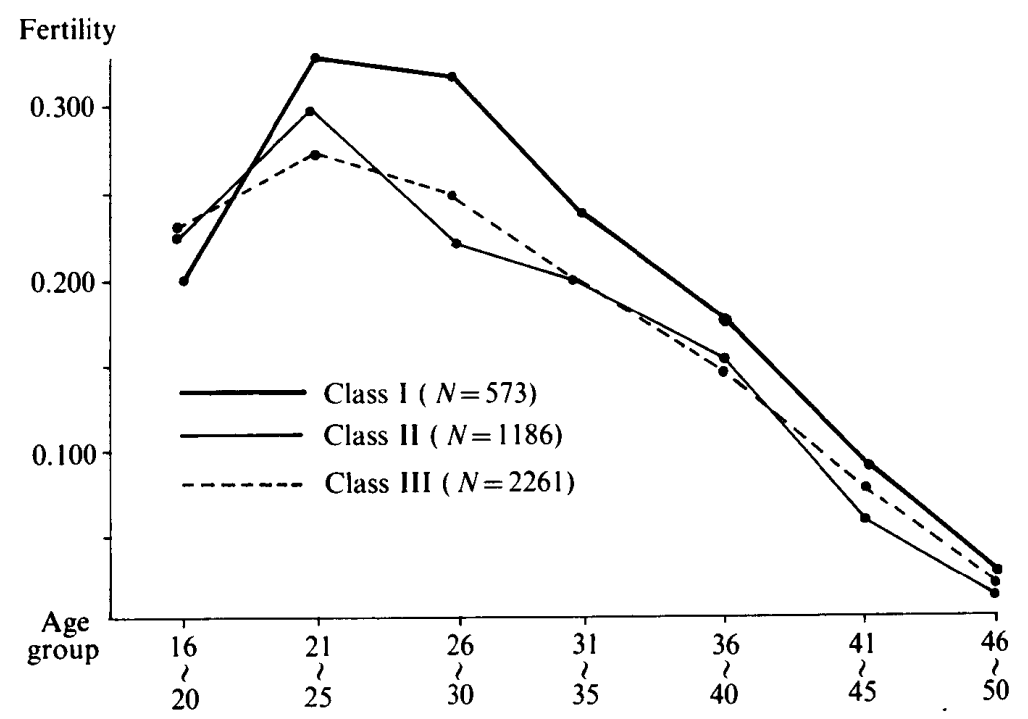

Fig. 5.1. Age specific fertility by class.

TABLE 5.1. AgE-SPECIFIC Fertility By Class

\begin{tabular}{|c|c|c|c|c|c|c|c|c|c|}
\hline \multirow{2}{*}{ Class } & \multicolumn{8}{|c|}{ Age Group } & \multirow{2}{*}{ Total } \\
\hline & Under 15 & $16-20$ & $21-25$ & $26-30$ & $31-35$ & $36-40$ & $41-45$ & $46-50$ & \\
\hline I & ${ }^{0}$ & $\begin{array}{r}0.218 \\
(60)\end{array}$ & $\begin{array}{l}0.324 \\
(162)\end{array}$ & $\begin{array}{l}0.291 \\
(146)\end{array}$ & $\begin{array}{l}0.242 \\
(103)\end{array}$ & $\begin{array}{r}0.174 \\
(68)\end{array}$ & $\begin{array}{r}0.088 \\
(28)\end{array}$ & $\begin{array}{c}0.025 \\
(6)\end{array}$ & $\begin{array}{l}0.215 \\
(573)\end{array}$ \\
\hline II & $\begin{array}{c}0.095 \\
(2)\end{array}$ & $\begin{array}{r}0.224 \\
(97)\end{array}$ & $\begin{array}{l}0.302 \\
(315)\end{array}$ & $\begin{array}{l}0.233 \\
(287)\end{array}$ & $\begin{array}{l}0.199 \\
(240)\end{array}$ & $\begin{array}{l}0.157 \\
(171)\end{array}$ & $\begin{array}{r}0.073 \\
(68)\end{array}$ & $\begin{array}{c}0.010 \\
(8)\end{array}$ & $\begin{array}{c}0.176 \\
(1188)\end{array}$ \\
\hline III & $\begin{array}{c}0.154 \\
(8)\end{array}$ & $\begin{array}{l}0.228 \\
(133)\end{array}$ & $\begin{array}{l}0.282 \\
(492)\end{array}$ & $\begin{array}{l}0.251 \\
(613)\end{array}$ & $\begin{array}{l}0.201 \\
(510)\end{array}$ & $\begin{array}{l}0.151 \\
(336)\end{array}$ & $\begin{array}{l}0.080 \\
(147)\end{array}$ & $\begin{array}{c}0.020 \\
(30)\end{array}$ & $\begin{array}{c}0.176 \\
(2269)\end{array}$ \\
\hline Total & $\begin{array}{c}0.111 \\
(10)\end{array}$ & $\begin{array}{l}0.224 \\
(290)\end{array}$ & $\begin{array}{l}0.295 \\
(969)\end{array}$ & $\begin{array}{c}0.250 \\
(1046)\end{array}$ & $\begin{array}{l}0.205 \\
(853)\end{array}$ & $\begin{array}{c}0.155 \\
(575)\end{array}$ & $\begin{array}{l}0.079 \\
(243)\end{array}$ & $\begin{array}{c}0.018 \\
(44)\end{array}$ & $\begin{array}{r}0.181 \\
(4030)\end{array}$ \\
\hline
\end{tabular}


Figure 5.1 is a graphic representation of Table 5.1. It shows directly that, with the exception of the youngest ages, the fertility of Class I is considerably higher than that of Classes II or III. Was the fertility of Class I in fact actually higher than that of the other two? High infant mortality rates, which varied by class, could result in such a difference. Population control may have been greater in Classes II and III. At the present time the author cannot give a definite answer as to which of these two possibilities is the more likely. But it is clear that there are obvious classbased differences in "fertility" as it is expressed in the shümon aratame chō.

These differences in fertility are reflected in the distribution of number of births to couples in each class. The 441 couples with completed families are divided into three classes and the distribution of number of births per class is shown in Table 5.2. On the average, couples of Class I have 1.7 to 1.9 more children than those in the other two classes.

Table 5.3 gives, for each class, an estimate of the number of children born to completed families where the wife marries between 16 sai and 30 sai, based on the age-specific fertility given in Table 5.1. At the same age at marriage, there is no conspicuous difference between classes in the number of births. However, based on his own previous research, the author believes that 4.5 births or more per family are necessary to maintain the reproduction of the family unit in agricultural villages at this period. Hence, if the woman does not marry at 24 sai or earlier in Class I, or at 22 sai or earlier in Classes II and III, the completed family will not be large enough to maintain itself as a unit.

However, as we have shown above in section three, marriage is earliest in Class I, and latest in Class III. In Classes II and III, as shown in Table 3.2, the average

TABLE 5.2. Number OF BiRTHS BY Class

\begin{tabular}{ccccc}
\hline \hline \begin{tabular}{c} 
Number $\begin{array}{c}\text { Cf } \\
\text { Births }\end{array}$ \\
\cline { 2 - 5 }
\end{tabular} & I & II & III & Total \\
\hline 0 & 1 & 15 & 38 & 54 \\
1 & 2 & 9 & 29 & 40 \\
2 & 2 & 13 & 29 & 44 \\
3 & 2 & 25 & 31 & 58 \\
4 & 7 & 13 & 27 & 47 \\
5 & 7 & 28 & 39 & 74 \\
6 & 4 & 32 & 53 \\
7 & 8 & 17 & 21 & 40 \\
8 & 4 & 2 & 8 & 14 \\
9 & 2 & 2 & 4 & 8 \\
10 & 3 & 1 & 4 & 8 \\
11 & 0 & 0 & 1 & 1 \\
Total & 42 & 136 & 263 & 341 \\
Mean & 5.6 & 3.9 & 3.7 & 3.9 \\
S.D. & 2.46 & 2.28 & 2.59 & \\
\hline
\end{tabular}


TABLE 5.3. Number OF Births to COMPleted FAMilies by WifE's Age at Marriage

\begin{tabular}{cccc}
\hline \hline \multirow{2}{*}{$\begin{array}{c}\text { Age at } \\
\text { marriage }\end{array}$} & \multicolumn{3}{c}{ Class } \\
\cline { 2 - 4 } & I & II & III \\
\hline 16 & 6.8 & 6.0 & 6.1 \\
17 & 6.6 & 5.8 & 5.8 \\
18 & 6.4 & 5.5 & 5.6 \\
19 & 6.2 & 5.3 & 5.4 \\
20 & 5.9 & 5.1 & 5.2 \\
21 & 5.7 & 4.9 & 4.9 \\
22 & 5.4 & 4.6 & 4.6 \\
23 & 5.1 & 4.3 & 4.4 \\
24 & 4.7 & 4.0 & 4.1 \\
25 & 4.4 & 3.7 & 3.8 \\
26 & 4.1 & 3.4 & 3.5 \\
27 & 3.8 & 3.1 & 3.3 \\
28 & 3.5 & 2.9 & 3.0 \\
29 & 3.2 & 2.7 & 2.8 \\
30 & 2.9 & 2.4 & 2.5 \\
\hline
\end{tabular}

age at marriage is close to the limit at which the family can be maintained. On the other hand, since the average age at marriage is much lower in Class I, 19.4 sai, one family can have six or more births. On the average, the number of children exceeds the number necessary to reproduce the family, so a household can establish branch households or supply husbands for daughters of households without their own sons. The combination of differing fertility and differences in age at marriage results in considerable variety in the distribution of number of births by class, as Table 5.2 shows.

In determining the total number of births one problematic factor is how long a wife continues to bear children. This is expressed as the wife's age at her final childbirth. If there were clear differences in the average age by class, it would be incumbent on us to include this in our consideration of the factors which influence fertility. One would expect that the age would be higher in the upper class and lower in the lower one. But in actual calculations it is difficult to discern any significant differences among the three classes. Our figures for the completed families in our sample show 39.1 sai for Class I, 38.1 sai for Class II, and 39.0 sai for Class III. At least for completed families, there is no process which equalizes the number of births by class through changes in the age at final birth. However, since there is a difference in duration of marriage by class, uncompleted families must also be included in our consideration of this question. Excluding the cases where the wife was under 50 sai and in a continuing marriage in the final year of the documents, there is a total of 872 couples in this sample. Age at last birth is $33.8 \mathrm{sai}$ in Class I, 34.3 sai in Class II, and 34.9 sai in Class III. The age at last birth is younger than the previous results, but one still cannot perceive any significant 
difference due to class. We can conclude that population was not limited by altering the wife's age at last birth, or, if it was, it did not vary by class.

\section{CONCLUSION}

The scope of this paper is limited, but its aim has been to examine whether there are class differences in demographic indices by examining the FRFs. The only measure in which there is no differential is age at marriage for men. We have detected significant class differences in both women's fertility and their age at marriage. In addition, there are clearly qualitative differences which result in a greater number of births in the higher classes and a fewer number in the lower ones. This shows that there was no limitation on the number of children in the economically prosperous classes; conversely, limitation did occur in the poorer ones.

Limiting the number of births by delaying marriage is what Malthus terms a preventative check. The low fertility involved here also suggests that the positive checks of abortion and infanticide were also operating. Let us consider which of these checks was more often employed by the poorer classes. It is clear from Table 3.2 that there was a difference of exactly three years in age at marriage, in both the mode and the mean, between Class I and Class III. Turning to Table 5.3, in Class I, when age at marriage is 19 sai, the number of births is 6.2. In Class III, when it is $22 \mathrm{sai}$, there are 4.6 births. Three years difference in age at marriage is accompanied by a difference of 1.6 in the number of births. If one holds age constant, there is a difference of 0.8 births between the two classes. A positive check of some sort causes this difference. Within a single class, as well, three years difference in age at marriage is accompanied by a difference of 0.8 in the number of births. That is to say, the proportions of the decrease in number of births attributable to the preventative check is exactly equivalent to the proportion attributable to the positive check. One cannot imagine that there was any factor which deliberately caused these two values to be consistent with each other. However, one thing remains to be said. This is that the poorer villagers in these six villages were consciously limiting the number of children they had. They did it through these two checks, positive and preventative. Villagers of the lower class, Class III, held the number of births down to the very limit at which the family unit could be reproduced, to the extent that there is a fair number of households which failed to produce an heir and became extinct. In the prosperous class, Class I, there was no need for population limitation, and, at least in the village of Nishijo, there is not a single case of a family of this class becoming extinct. ${ }^{7}$

Our examples come from only a few of the fifty or sixty thousand villages which existed in Japan during the 270 years of the Tokugawa period. The problem of whether these examples are representative of the entire country remains. But we

7 For class differences in the formation of branch households and the extinction of households in the village of Nishijo, see Hayami (1973a), Table IX, page 17. 
can now take the statement that the villagers exhibited different demographic behavior dependent on the class to which they belonged as an established fact. Further research must take full account of this and be concerned with defining its limits.

Keio University

\section{REFERENCES}

Hanley, Susan B., and Yamamura, Kozo (1977). Economic and Demographic Change in Preindustrial Japan, 1600-1868, Princeton: Princeton University Press.

Hayami, Akira (1973a). "Labor Migration in a Pre-industrial Society: A Study Tracing the Life Histories of the Inhabitants of a Village," Keio Economic Studies, Vol. X, No. 2, 1-17.

(1973b). "Jinkōgakuteki shihyō ni okeru kaisokan no kakusa," Tokugawa Rinseishi Kenkyūjo, Kenkyū kiȳ̄, 178-193.

Kito, Hiroshi (1976). "Tokugawa jidai nōson no nyūji shibō," Mita Gakkai Zasshi, Vol. LXIX, No. 8, 88-95.

Smith, Thomas C. (1977). Nakahara: Family Farming and Population in a Japanese Village, 1717-1830, Stanford: Stanford University Press. 